\title{
Speciation of Fe(II) and Fe(III) by using Dispersive Liquid-Liquid Microextraction and Flame Atomic Absorption Spectrometry
}

\author{
Soleiman Bahar* and Razieh Zakerian \\ Department of Chemistry, Faculty of Science, University of Kurdistan, P. O. Box 416, Sanandaj, Iran
}

\begin{abstract}
Um método de extração de Fe(III) em amostras de água prévio à determinação espectrométrica foi desenvolvido. Microextração dispersiva líquido-líquido (DLLME) foi usada com sucesso como método de preparação de amostras para espectrometria de absorção atômica por chama (FAAS). $\mathrm{Na}$ abordagem proposta, 8-hidroxiquinolina (oxina) foi usada como agente quelante, clorofórmio e metanol foram selecionados como solventes extrator e dispersivo, respectivamente. Alguns fatores influenciando a eficiência da extração de Fe(III) e sua subsequente determinação foram estudados e otimizados, incluindo: tipo e volume de solventes extrator e dispersor, pH da solução da amostra, concentração do agente quelante e tempo de extração. Nas condições otimizadas, o fator de enriquecimento deste método para $\mathrm{Fe}(\mathrm{III})$ foi 462. O limite de detecção para $\mathrm{Fe}(\mathrm{III})$ foi $4,5 \mathrm{ng} \mathrm{mL}^{-1}$, e o desvio padrão relativo (RSD) $1,4 \%\left(\mathrm{n}=5, \mathrm{c}=400 \mathrm{ng} \mathrm{mL}^{-1}\right)$.
\end{abstract}

An extraction method for Fe(III) from water sample before spectrometric determination was developed. Dispersive liquid-liquid microextraction (DLLME) technique was successfully used as sample preparation method for flame atomic absorption spectrometry (FAAS). In the proposed approach, 8-hydroxy quinoline (oxine) was used as chelating agent, chloroform and methanol were selected as extraction and dispersive solvents, respectively. Some factors influencing the extraction efficiency of $\mathrm{Fe}(\mathrm{III})$ and its subsequent determination were studied and optimized, including: type and volume of extraction and dispersive solvents, $\mathrm{pH}$ of sample solution, concentration of the chelating agent and extraction time. Under the optimized conditions, the enrichment factor of this method for Fe(III) was 462. The limit of detection for Fe(III) was $4.5 \mathrm{ng} \mathrm{mL}^{-1}$, and the relative standard deviation $(\mathrm{RSD}) 1.4 \%\left(\mathrm{n}=5, \mathrm{c}=400 \mathrm{ng} \mathrm{mL} \mathrm{m}^{-1}\right)$.

Keywords: dispersive liquid-liquid microextraction, $\mathrm{Fe}(\mathrm{II}), \mathrm{Fe}(\mathrm{III})$, flame atomic absorption spectrometry, water samples

\section{Introduction}

Due to the importance of heavy metals at trace level in the human health and environment, the sensitive and accurate determination of the levels of heavy metals in the environmental samples have been continuously carried out on the analytical and environmental laboratories around the world. ${ }^{1-3}$ Among heavy metals, iron in small amounts is an essential element for most life on Earth, including humans and animals. It is well known that an iron deficiency is the most common cause of anemia. On the other hand, too much iron can cause several health problems. High levels of iron are associated with an increased risk for cancer, heart disease and other illnesses such as endocrine problems, arthritis, diabetes and liver

*e-mail: s.bahar@uok.ac.ir, soleiman.bahar@yahoo.com disease. ${ }^{4}$ A sanitary security limit for iron was restricted to $2 \mathrm{mg} \mathrm{L}^{-1}$ by World Health Organization. ${ }^{5}$ European Legislation has established a maximum contaminant level (MCL) at $200 \mu \mathrm{g} \mathrm{\textrm {L } ^ { - 1 }}$ for iron. ${ }^{6}$

Several analytical techniques such as flame atomic absorption spectrometry (FAAS), graphite furnace atomic absorption spectrometry (GFAAS), inductively coupled plasma mass spectrometry (ICP-MS) have been proposed for the determination of trace and toxic metals in different environmental sample. FAAS is one of the widespread traditional analytical techniques for the determination of trace elements, but it often suffers from its low sensitivity. The determination of trace quantity of heavy metals in environmental samples, like natural water and other real samples of environmental interest in which they are found at very low concentrations, requires the use of preconcentration methods coupled to spectrometric 
methods, such as ICP-AES (inductively coupled plasma atomic emission spectrometry) and FAAS.

Techniques such as co-precipitation, ${ }^{7}$ solid phase extraction, ${ }^{8,9}$ liquid-liquid extraction ${ }^{10,11}$ are widely used in the separation and preconcentration of trace elements. A new trend in analytical chemistry is the miniaturization of preconcentration systems with the aim of minimizing reagent consumption and waste generation. ${ }^{12}$ For liquid-liquid extraction, alternatives of miniaturization can be employed with strategies such as liquid-liquid microextraction (LLME) ${ }^{13}$ single drop microextraction (SDME) and dispersive liquid-liquid microextraction (DLLME).$^{14}$

Dispersive liquid-liquid microextraction is a preconcentration technique that employs a ternary system of solvents. This technique was reported for the first time in a procedure for the determination of organophosphorus pesticides in water. ${ }^{15}$ However, DLLME has also been used for the extraction and preconcentration of inorganic compounds, offering advantages such as ease of operation, use of small quantities of sample and organic solvents, speed of analysis, low cost and high recoveries and enrichment factors. ${ }^{16-20}$ In DLLME, a mixture containing appropriate amounts of extraction and disperser solvents is rapidly injected into an aqueous sample with the aid of a syringe. Then, a cloudy solution is formed and the analyte is extracted into the interior of the droplets of the extraction solvent. After the extraction, the phase separation is accomplished by centrifugation, and the analyte is determined in the sedimented phase. For the determination of metal trace elements, a complexing reagent should be dissolved in the mixture. ${ }^{21}$ To the best of our knowledge, there are only two reports for iron speciation and determination using the DLLME method based on ion-association formation and combination of artificial networks and DLLME based on solidification of floating organic drop. ${ }^{22,23}$

The present work describes the attempt for the preconcentration and speciation of iron ions from aqueous samples using 8-hydroxy quinoline as complexing reagent. After optimization of experimental variables and determination of analytical characteristics, the method was evaluated for application in real samples.

\section{Experimental}

\section{Apparatus}

An atomic absorption spectrometer (Shimadzu, AA-670) equipped with flame module was used for the determination of iron by using the manufacturer recommendations. A PHS-25CW Microprocessor $\mathrm{pH} / \mathrm{mV}$
Meter equipped with a combined glass-calomel electrode was used for determining $\mathrm{pH}$ values. A laboratory centrifuge (Heraeus, Labofuge 400 model, Germany) was used to accelerate the phase separation and a Hamilton syringe was used for the injection.

\section{Standard solution and reagents}

All reagents and solvents such as iron(III) nitrate nonahydrate, iron(II) ammonium sulfate hexahydrate, 8-hydroxy quinoline, $o$-phenanthroline, methanol, ethanol, acetone, tetrahydrofurane (THF), acetonitrile (ACN), chloroform, carbon tetrachloride, dichloromethane, carbon disulfide, sodium chloride and nitric acid were high purity grade reagents ${ }^{17}$ from Merck Co. (Darmstadt, Germany). Double distilled water was used in the whole procedure. Stock standard solutions of $\mathrm{Fe}^{3+}$ and $\mathrm{Fe}^{2+}$ at concentration of $1000 \mu \mathrm{g} \mathrm{mL}^{-1}$ were prepared by dissolving $0.1803 \mathrm{~g}$ of iron(III) nitrate nonahydrate in $25 \mathrm{~mL}$ of $1.5 \mathrm{~mol} \mathrm{~L}^{-1}$ nitric acid, and $0.175 \mathrm{~g}$ of iron(II) ammonium sulfate hexahydrate in $25 \mathrm{~mL}$ sulfuric acid ( $\mathrm{pH}$ 2). The solutions of lower concentrations were daily prepared by a suitable dilution of the stock solution with distilled water. The solution of oxine $\left(0.05 \mathrm{~mol} \mathrm{~L}^{-1}\right)$ was prepared by dissolving appropriate amounts of oxine in methanol. A $0.01 \mathrm{~mol} \mathrm{~L}^{-1}$ solution of $o$-phenanthroline was prepared by dissolving appropriate amount of this reagent in ethanol. Vessels in the experiments were kept in $10 \%$ nitric acid for at least $24 \mathrm{~h}$, and subsequently washed with double distilled water. The developed method was successfully applied to water samples. Tap, well, mineral (obtained from local sources) and Caspian Sea water samples used for the development of the method were collected in PTFE containers and analyzed without any previous treatment or filtration.

\section{Dispersive liquid-liquid microextraction procedure}

In a typical experiment, $1 \mathrm{~mL}$ of phosphate buffer $\left(0.1 \mathrm{~mol} \mathrm{~L}^{-1}, \mathrm{pH} 3\right)$ and $0.5 \mathrm{~mL}$ of $0.05 \mathrm{~mol} \mathrm{~L}^{-1} 8$-hydroxy quinoline solution were added to $5.0 \mathrm{~mL}$ of aqueous solution containing $0.1 \mu \mathrm{g} \mathrm{mL}-1 \mathrm{Fe}(\mathrm{III})$ in a 10 -mL test tube with conical bottom. After $4 \mathrm{~min}, 2 \mathrm{~mL}$ of methanol containing $200 \mu \mathrm{L}$ of chloroform were added to the above solution by using a $5 \mathrm{~mL}$ syringe. The mixture was immediately centrifuged for $5 \mathrm{~min}$ at $3000 \mathrm{rpm}$. The volume of the sedimented phase (chloroform) was determined using a $100 \mu \mathrm{L}$ Hamilton syringe. The sedimented phase was transferred to another test tube and allowed to evaporate at room temperature. Finally, the residue was dissolved into $0.5 \mathrm{~mL}$ of $1.5 \mathrm{~mol} \mathrm{~L}^{-1}$ nitric acid, and the $\mathrm{Fe}$ (III) concentration was determined by flame atomic absorption 
spectrometry. Fe(III) standard solutions $\left(0.2-2.2 \mu \mathrm{g} \mathrm{mL} L^{-1}\right)$ obtained by serial dilutions of the stock solution with double distilled water were daily prepared and their absorbance was read along with samples.

\section{DLLME procedure for real samples}

Aliquots of $5 \mathrm{~mL}$ of each sample along with $0.5 \mathrm{~mL}$ of $0.01 \mathrm{~mol} \mathrm{~L}^{-1} o$-phenanthroline for masking $\mathrm{Fe}(\mathrm{II})$ ions were subjected to the dispersive liquid-liquid microextraction method. For determining the total iron to $50 \mathrm{~mL}$ of each sample, $250 \mu \mathrm{L}$ of concentrated nitric acid were added, then the samples were heated for $10 \mathrm{~min}$ for the Fe(II) oxidation. After heating, the samples were diluted by distillated water to $50 \mathrm{~mL}$ to compensate the evaporated water, and $5 \mathrm{~mL}$ of each of the diluted samples were subjected to DLLME. The Fe(II) concentration in the sample solution could therefore be calculated by subtracting $\mathrm{Fe}(\mathrm{III})$ from total iron.

\section{Results and Discussion}

For higher sensitivity, selectivity and precision for iron determination with the DLLME method, the effect of the main parameters, like the type of dispersive and extraction solvents, sample acidity, amount of chelating agent, sample ionic strength and extraction time were studied and optimized. To study these influential parameters, enrichment factor (EF) and recovery percent were used to evaluate the extraction efficiency under different conditions. The enrichment factor was defined as the ratio between the analyte concentration in the sedimented phase $\left(\mathrm{C}_{\text {sed }}\right)$ and the initial concentration of analyte $\left(\mathrm{C}_{0}\right)$ within the sample

$\mathrm{EF}=\frac{\mathrm{C}_{\mathrm{sed}}}{\mathrm{C}_{\mathrm{o}}}$

The extraction recovery was defined as the percentage of the total amount of analyte $\left(\mathrm{m}_{\mathrm{o}}\right)$, which was extracted into the sedimented phase:

$R(\%)=\left(\frac{m_{\text {sed }}}{m_{o}}\right) 100=\left(\frac{C_{\text {sed }}}{C_{o}}\right)\left(\frac{V_{\text {sed }}}{V_{\text {aq }}}\right) 100$

where $\mathrm{V}_{\text {sed }}, \mathrm{V}_{\mathrm{aq}}, \mathrm{C}_{0}, \mathrm{C}_{\text {sed }}, \mathrm{m}_{\mathrm{o}}$ and $\mathrm{m}_{\text {sed }}$ are the volume of sedimented phase, volume of sample solution, initial concentration of analyte in aqueous sample and the concentration of analyte in sedimented phase, amount of analyte in sedimented phase and the initial amount of analyte, respectively. The $\mathrm{C}_{\text {sed }}$ was calculated by the calibration graph obtained from standard solutions of $\mathrm{Fe}(\mathrm{III})$ and the sedimented phase volume.

\section{Effect of extraction and dispersive solvent types}

The type of extraction solvent used in DLLME was an essential consideration for an efficient extraction. It should have higher density than water, high extraction capability of the compounds of interest and low solubility in water. Chloroform $\left(\mathrm{CHCl}_{3}\right)$, carbon tetrachloride $\left(\mathrm{CCl}_{4}\right)$, dichloromethane $\left(\mathrm{CH}_{2} \mathrm{Cl}_{2}\right)$ and carbon disulfide $\left(\mathrm{CS}_{2}\right)$ were studied as extraction solvents. For DLLME method, the dispersive solvent should be miscible with both water and extraction solvent. In this work, methanol, ethanol, acetonitrile, tetrahydrofuran and acetone were investigated as the dispersive solvents. The effect of these extraction and dispersive solvents on the extraction efficiency of DLLME were tested using $2 \mathrm{~mL}$ and $200 \mu \mathrm{L}$ of each dispersive and extraction solvents, respectively. In Figure 1, EF and recovery are shown for all combinations of dispersive and extracting solvents. Regarding EF and recovery, the combination of chloroform as extracting solvent with methanol as dispersive solvent were the best and an EF higher than 120 was attainable. Note that in the case of dichloromethane as extracting solvent and methanol, ethanol, acetonitrile and acetone as dispersive solvents, no sedimented phase was obtained. On the other hand, in the combination of dichloromethane-THF and carbon disulfide-THF, the sedimented phases were formed in the upper of the conical test tube and the separation of the sedimented phases was difficult, hence these conditions were useless.

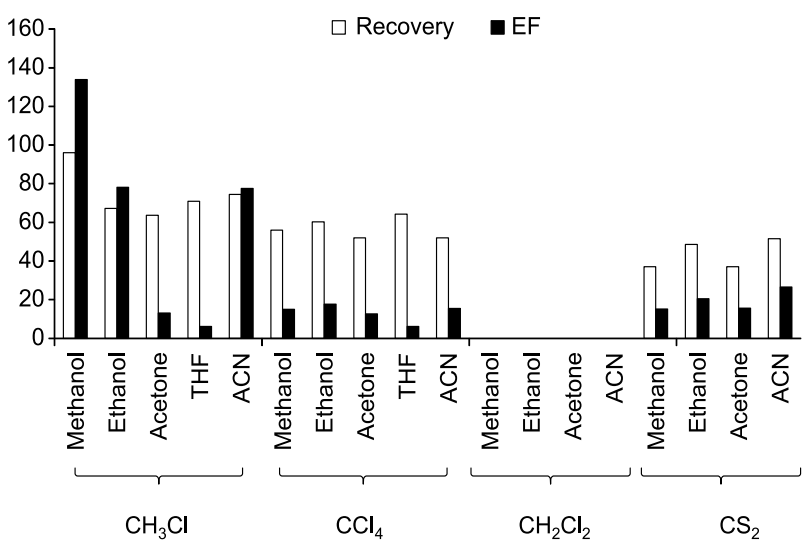

Figure 1. The selection of extraction and dispersive solvents in DLLME. Extraction condition: water sample volume of $5 \mathrm{~mL}\left(100 \mathrm{ng} \mathrm{mL}^{-1}\right)$, solvent volume of $2 \mathrm{~mL}$, extraction solvent volume of $200 \mu \mathrm{L}, 1 \mathrm{~mL}$ phosphate buffer $(\mathrm{pH} 7)$ and $0.5 \mathrm{~mL}$ oxine solution $\left(0.05 \mathrm{~mol} \mathrm{~L}^{-1}\right)$ in methanol.

\section{Effect of dispersive solvent volume}

The effect of the volume of methanol on the extraction efficiency was examined. To obtain the optimized volume of methanol, various experiments were performed using different volumes of methanol in range of $0-3.5 \mathrm{~mL}$ along 
with $200 \mu \mathrm{L}$ of chloroform as extracting solvent of Fe(III) ions. The obtained results (Figure 2) were showed by increasing the methanol volume to $2 \mathrm{~mL}$, the enrichment factor and recovery increased. Furthermore, in the case of $2.5 \mathrm{~mL}$ of methanol, the recovery and sedimented volume decreased to $27 \%$ and $4 \mu \mathrm{L}$ ( $\mathrm{EF}$ is more than 300 ), respectively, and with $3 \mathrm{~mL}$ or higher volume of methanol, no sedimented phase was achieved. Finally, $2 \mathrm{~mL}$ of methanol was chosen as the optimum volume.

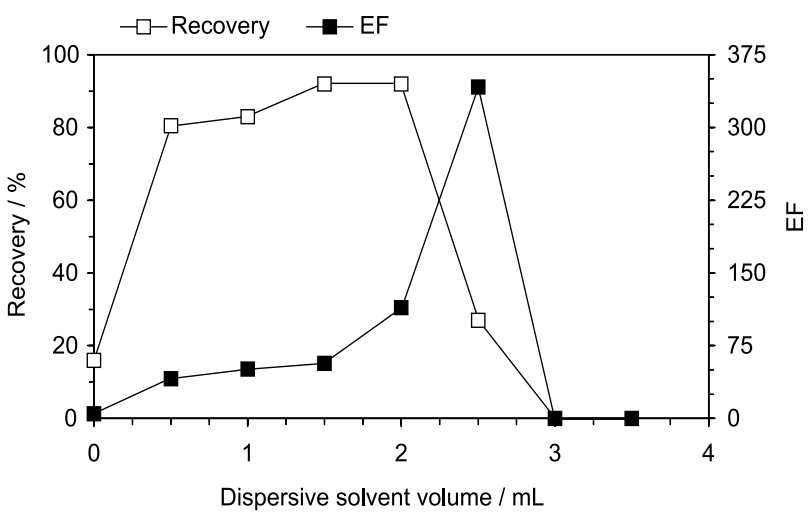

Figure 2. The selection of the dispersive solvent volume. Other conditions are the same as Figure 1.

\section{Effect of extraction solvent volume}

In order to examine the effect of the extraction solvent volume, the solutions containing different volumes of chloroform in range of $50-500 \mu \mathrm{L}$ were subjected to the same DLLME procedure. As can be seen in Figure 3, there was no sedimented phase by using 50, 100 and $150 \mu \mathrm{L}$, and the system became useless. On the other hand, in more than $200 \mu \mathrm{L}$ of chloroform, the enrichment factor decreased because the sedimented phase volume increased. Subsequently, at $200 \mu \mathrm{L}$ volume of the extraction solvent, high enrichment factor and recovery were obtained. Therefore, $200 \mu \mathrm{L}$ of chloroform was used as the optimum volume of the extraction solvent.

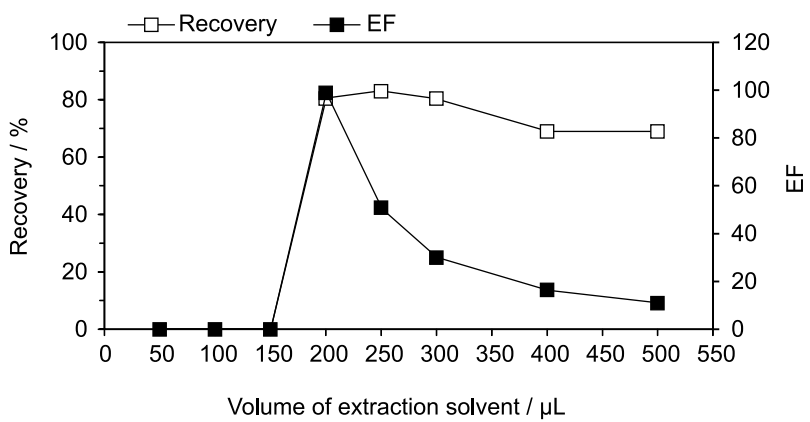

Figure 3. The effect of the extraction solvent volume on the recovery and on the enrichment factor in the extraction $\mathrm{Fe}^{3+}$ by DLLME. Other conditions are the same as Figure 1.

\section{Effect of extraction time}

In DLLME, the extraction time is defined as the time between the injection of the dispersive solvent (methanol) and extraction solvent (chloroform), and before starting the centrifugation. The effect of extraction time was examined in the ranges of $5 \mathrm{~s}$ to $60 \mathrm{~min}$ under constant experimental conditions. The obtained results showed that the extraction time had no significant influence on the signal of $\mathrm{Fe}(\mathrm{III})$. Because of the infinitely large surface area between the extraction solvent and aqueous phase after the formation of cloudy solution, the complex of $\mathrm{Fe}^{3+}$ and oxine was quickly diffused into the extraction solvent. Therefore, the DLLME method was time independent, which is the most important advantage of this technique.

\section{Effect of ionic strength}

The influence of ionic strength of the aqueous solutions on the extraction efficiency was evaluated by adding various amounts of sodium chloride $(\mathrm{NaCl})$ in the range of $0.02-0.2 \mathrm{~g} \mathrm{~mL}^{-1}$. Other experimental conditions were kept constant. No significant impact on the recovery percent was observed in the studied range. However, by increasing sodium chloride concentration from 0.02 to $0.2 \mathrm{~g} \mathrm{~mL}^{-1}$, the solubility of the extraction solvent in the aqueous phase decreased. As a result, the volume of sedimented phase increased from 70 to $91 \mu \mathrm{L}$. Therefore, the increased volume of the sedimented phase reduced the enrichment factor from 57.92 to 34.88 (Figure 4). These observations revealed the possibility of using this method for the Fe(III) separation from saline solutions up to $20 \%(\mathrm{~m} / \mathrm{v})$.

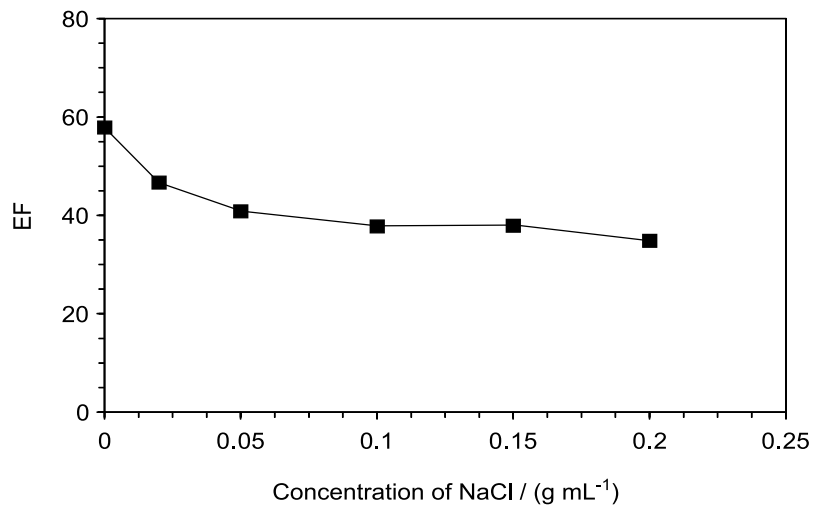

Figure 4. The effect of the $\mathrm{NaCl}$ amount on the enrichment factor. Other conditions are the same as Figure 1.

\section{Effect of sample acidity and oxine concentration}

Among chemical variables, sample acidity, which is defined by the $\mathrm{pH}$ of the sample solution, played a 
significant role in the overall performance of the solvent extraction, affecting the complex formation and the extraction efficiency. The $\mathrm{pH}$ effect on the absorbance was studied in the range of 2-12 by adjusting the Fe(III) solution with phosphate buffer. According to Figure 5, the $\mathrm{pH}$ range of maximum extraction of $\mathrm{Fe}(\mathrm{III})$ was between 3 and 5 . On the other hand, the obtained results showed that the $\mathrm{pH}$ influenced the sedimented phase volume. At $\mathrm{pH} 3$, the highest EF and recovery were obtained. Therefore, $\mathrm{pH} 3$ was selected in subsequent experiments to adjust the $\mathrm{pH}$ of the $\mathrm{Fe}(\mathrm{III})$ solution.

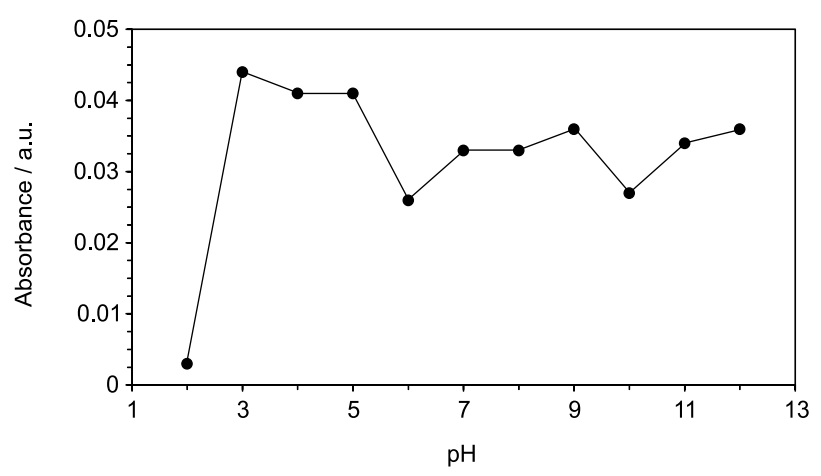

Figure 5. The pH effect on the extraction efficiency of Fe(III). Other conditions are the same as Figure 1.

In addition, the influence of 8-hydroxy quinoline concentration on the extraction in the ranges of $0.001-0.1 \mathrm{~mol} \mathrm{~L}^{-1}$ in methanol was studied. The results are shown in Figure 6, in $0.05 \mathrm{~mol} \mathrm{~L}^{-1}$ 8-hydroxy quinoline, $\mathrm{EF}$ and recovery were maximum. Thus, a concentration of $0.05 \mathrm{~mol} \mathrm{~L}^{-1} 8$-hydroxy quinoline was used as optimum amount in subsequent experiments.

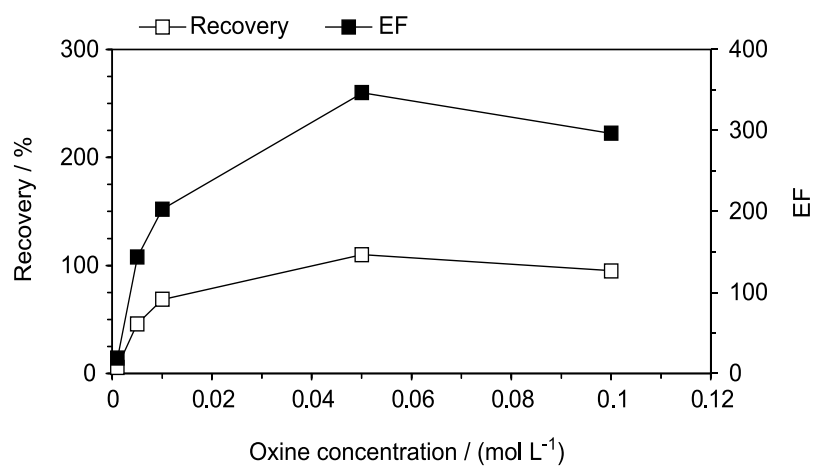

Figure 6. The effect of the oxine concentration on the extraction efficiency of $\mathrm{Fe}(\mathrm{III})$. Other conditions are the same as Figure 1.

\section{Effect of other parameters}

The influence of reaction time on the extraction was studied over the ranges of 0-10 min. It was defined as the time spent between the addition of oxine solution and the addition of the extraction solvent dissolved in the dispersive solvent. The obtained results showed that after $4 \mathrm{~min}$, the recovery was the highest one.

The effect of centrifugation time in the dispersive liquid-liquid microextraction of iron using oxine in the ranges of 1-10 min was also studied. The results showed that the recovery and EF were increased from 1 to $5 \mathrm{~min}$. However, after 5 min of centrifugation, EF reduced because of the increasing sedimented phase volume. Therefore, a centrifugation time of 5 min was used in all subsequent experiments.

\section{Interferences}

The effect of interference ions in the present method was investigated. The interference was due to the competition of other metal ions for the chelating agent and their subsequent coextraction with iron. In these experiments, $5 \mathrm{~mL}$ of solutions containing $100 \mu \mathrm{g} \mathrm{L} \mathrm{L}^{-1}$ of $\mathrm{Fe}(\mathrm{III})$ and various amounts of interfering ions were treated according to the dispersive liquid-liquid microextraction procedure. The limits of tolerance of the coexisting ions, defined as the largest amount making the recovery of Fe less than 90\%, are given in Table 1.

Table 1. The effect of the foreign ions on dispersive liquid phase microextraction of $\mathrm{Fe}^{3+}$ using oxine

\begin{tabular}{lc}
\hline Interfering ions & $\begin{array}{c}\text { Tolerable concentration } \\
\text { (analyte: interfering ion) }\end{array}$ \\
\hline $\mathrm{Hg}^{+2}$ & $1: 10$ \\
$\mathrm{Cr}^{+3}$ & $1: 100$ \\
$\mathrm{Cu}^{+2}, \mathrm{~Pb}^{+2}$ & $1: 1000$ \\
$\mathrm{Ag}^{+}, \mathrm{Mg}^{+2}, \mathrm{Ba}^{+2}, \mathrm{Ni}^{+2}, \mathrm{Cl}^{-}$ & $1: 10000$ \\
$\mathrm{~K}^{+}, \mathrm{Br}^{-} \mathrm{IO}_{3}^{-}$ & $1: 100000$ \\
\hline
\end{tabular}

${ }^{\mathrm{a}}$ At this ratio interfering effect was observed.

\section{Evaluation of method performance}

For the purpose of quantitative analysis, under the optimum conditions (sample size of $5 \mathrm{~mL}$, dispersive solvent (methanol) volume of $2 \mathrm{~mL}$, extraction solvent (chloroform) volume of $200 \mu \mathrm{L}, 1 \mathrm{~mL}$ phosphate buffer $\left(1 \mathrm{~mol} \mathrm{~L}^{-1}\right)$ $\mathrm{pH} 3$ and $0.5 \mathrm{~mL}$ of $0.05 \mathrm{~mol} \mathrm{~L}^{-1}$ 8-hydroxy quinoline solution in methanol), some analytical characteristics of the proposed DLLME method were obtained. Analytical characteristics of the optimized method, including the linear range, the square of correlation coefficient $\left(\mathrm{R}^{2}\right)$, the limit of detection (LOD), the limit of quantitation (LOQ), the relative standard deviation (RSD) and enrichment and enhancement factors are listed in Table 2. The calibration curve was linear in the range of $50-1000 \mathrm{ng} \mathrm{mL}^{-1}$ of $\mathrm{Fe}(\mathrm{III})$. The limit 
of detection (signal/noise ratio $=3$ ) was $4.5 \mathrm{ng} \mathrm{mL}^{-1}$. The limit of quantitation is the lowest level of analyte that can be accurately and precisely measured. LOQ defined as 10 times the standard deviation $(10 \mathrm{~s})$ of 10 measurements was found as $51 \mathrm{ng} \mathrm{mL}^{-1}$. The relative standard deviation for replicate 5 measurements of $\mathrm{Fe}(\mathrm{III})$ was $1.4 \%\left(\mathrm{c}=400 \mathrm{ng} \mathrm{mL}^{-1}\right)$. Some characteristics of previously reported methods such as enrichment factor and limit of detection are summarized in Table 3 for the comparison. As it can be seen, the proposed

Table 2. Analytical characteristics of the method for Fe(III)

\begin{tabular}{lc}
\hline Parameter & Analytical feature \\
\hline Linear range / $\left(\mathrm{ng} \mathrm{mL}^{-1}\right)$ & $50-1000$ \\
Square of correlation coefficient $\left(\mathrm{R}^{2}\right)$ & 0.999 \\
Limit of detection / $\left(\mathrm{ng} \mathrm{mL}^{-1}\right)$ & 4.5 \\
Limit of quantitation / $\left(\mathrm{ng} \mathrm{mL}^{-1}\right)$ & 51 \\
Repeatability (RSD) & 1.4 \\
Enrichment (enhancement $\left.\mathrm{a}^{\mathrm{a}}\right)$ factor & $462(15)$ \\
Sample volume / $\mathrm{mL}$ & 5 \\
\hline
\end{tabular}

${ }^{\mathrm{a} E n h a n c e m e n t ~ f a c t o r ~ i s ~ t h e ~ s l o p e ~ r a t i o ~ o f ~ c a l i b r a t i o n ~ g r a p h ~ a f t e r ~ a n d ~}$ before extraction.
DLLME method in this work, for the precocentration of $\mathrm{Fe}(\mathrm{III})$ ions, showed a high enrichment factor in comparison to the mentioned methods and had relative low limit of detection. On the other hand, the low cost and simplicity as well as its high selectivity for iron ions made it as a suitable quantitative determination method. The method was successfully applied to the determination of $\mathrm{Fe}(\mathrm{II})$ and $\mathrm{Fe}(\mathrm{III})$ amounts in water samples.

\section{Application of the method}

The proposed method was applied to the determination of $\mathrm{Fe}(\mathrm{II})$ and $\mathrm{Fe}(\mathrm{III})$ in tap water, well water, mineral water and Caspian Sea water. The results are listed in Table 4. In order to validate the applicability of the proposed procedure, aliquots of $5.0 \mathrm{~mL}$ of different samples were spiked with known concentrations of $\mathrm{Fe}$ (II) and $\mathrm{Fe}$ (III) and recovery experiments were conducted as well for these samples. The results summarized in Table 4 showed that satisfactory recoveries in the range of $92-105 \%$ were achieved for these real samples. The results of this investigation are given in Table 4. In addition, these results

Table 3. The analytical characteristics of the different extraction methods

\begin{tabular}{|c|c|c|c|c|c|c|c|c|}
\hline Method & $\begin{array}{c}\text { Extraction } \\
\text { method }\end{array}$ & $\begin{array}{c}\text { Concentration } \\
\text { range / }\left(\mathrm{ng} \mathrm{mL}^{-1}\right)\end{array}$ & $r^{2}$ & $\mathrm{RSD} / \%$ & $\mathrm{R}^{\mathrm{a}} / \%$ & $\mathrm{EF}^{\mathrm{b}}$ & $\mathrm{LOD} /\left(\mathrm{ng} \mathrm{mL}^{-1}\right)$ & Ref. \\
\hline Spectophotormetry & DLLME & $250-1000$ & 0.996 & 1.2 & $90-108$ & 5 & 7.5 & 22 \\
\hline Spectophotormetry & DLLME-SFO & $310-350$ & 0.9987 & 3.9 & - & 162 & 8 & 23 \\
\hline GFAAS & CPE & $0-80$ & 0.9968 & 4.2 & 94 & 25 & 0.08 & 24 \\
\hline ICP-AES & SPE & - & - & 2.0 & $95-105$ & 75 & 0.34 & 25 \\
\hline FAAS & SPE & $0.2-680$ & - & 1.5 & 100 & 100 & 0.02 & 26 \\
\hline FAAS & LLE & $250-150$ & 0.9976 & 7.0 & 90 & - & 9 & 27 \\
\hline FAAS & DLIME & $50-1000$ & 0.999 & 1.4 & $96-101$ & 462 & 4.5 & this work \\
\hline
\end{tabular}

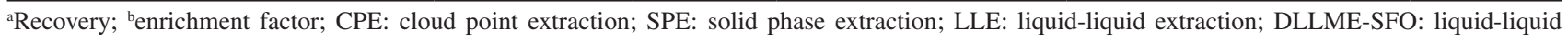
microextraction combined with a solidification of a floating organic drop; RSD: relative standard deviation; LOD: limit of detection.

Table 4. The analytical results (mean \pm standard deviation, $\mathrm{n}=3$ ) for determination of $\mathrm{Fe}(\mathrm{III})$ and $\mathrm{Fe}(\mathrm{II})$ in real water samples

\begin{tabular}{|c|c|c|c|c|c|c|}
\hline \multirow{2}{*}{ Sample } & \multicolumn{2}{|c|}{ Added / $\left(\mathrm{ng} \mathrm{mL}^{-1}\right)$} & \multicolumn{2}{|c|}{ Found / $\left(\mathrm{ng} \mathrm{mL}^{-1}\right)$} & \multicolumn{2}{|c|}{ Recovery / \% } \\
\hline & $\mathrm{Fe}(\mathrm{III})$ & $\mathrm{Fe}(\mathrm{II})$ & $\mathrm{Fe}(\mathrm{III})$ & $\mathrm{Fe}(\mathrm{II})$ & $\mathrm{Fe}(\mathrm{III})$ & $\mathrm{Fe}(\mathrm{II})$ \\
\hline \multirow[t]{3}{*}{ Tap water } & - & - & $85 \pm 3$ & $0 \pm 1$ & - & - \\
\hline & 100 & - & $187 \pm 2$ & $0 \pm 1$ & 102 & - \\
\hline & - & 100 & $85 \pm 3$ & $99 \pm 2$ & - & 99 \\
\hline \multirow[t]{3}{*}{ Mineral water } & - & - & $22 \pm 2$ & $10 \pm 1$ & - & - \\
\hline & 100 & - & $118 \pm 4$ & $10 \pm 1$ & 96 & - \\
\hline & - & 100 & $22 \pm 2$ & $111 \pm 4$ & - & 101 \\
\hline \multirow[t]{3}{*}{ Well water } & - & - & $85 \pm 4$ & $26 \pm 2$ & - & - \\
\hline & 100 & - & $185 \pm 4$ & $26 \pm 2$ & 100 & - \\
\hline & - & 100 & $85 \pm 4$ & $120 \pm 2$ & - & 94 \\
\hline \multirow[t]{3}{*}{ Caspian Sea water } & - & - & $280 \pm 6$ & $236 \pm 8$ & - & - \\
\hline & 100 & - & $385 \pm 5$ & $236 \pm 8$ & 105 & - \\
\hline & - & 100 & $280 \pm 6$ & $328 \pm 6$ & - & 92 \\
\hline
\end{tabular}


indicated that no significant matrix effect was observed in the proposed procedure.

\section{Conclusions}

In this study, the determination of $\mathrm{Fe}(\mathrm{II})$ and $\mathrm{Fe}(\mathrm{III})$ in water samples by dispersive liquid-liquid microextraction combined with flame atomic absorption spectrometry was shown as a routine and efficient method. The important features of DLLME method were low cost, the use of minimized toxic organic solvents, the simplicity of operation, the rapidity, the high enrichment factor and good sensitivity and selectivity. Enrichment factor and recovery for the target analyte were obtained about 462 and more than $95 \%$, respectively. The proposed extraction method was used for the quantitation of iron ions in water samples.

\section{Acknowledgement}

The authors acknowledge for financial support of this investigation by the University of Kurdistan.

\section{References}

1. Ekici, K.; Agaoglu, S.; Isleyici, O.; Indian Vet. J. 2004, 81, 1284.

2. Mico, C.; Peris, M.; Sanchez, J.; Recatala, L.; Span. J. Agric. Res. 2006, 4, 363.

3. Al-Khashman, O. A.; Environ. Geochem. Health 2007, $29,1$.

4. Niederau, C.; Fischer, R.; Purschel, A.; Stremmel, W.; Haussinger, D.; Gastroenterology 1996, 110, 1107.

5. http://www.who.int/water_sanitation_health/dwq/ nutrconsensusrep.pdf accessed in August 2004.

6. http://rod.eionet.europa.eu/instruments/545 accessed in November 1998.

7. Bispo, M. S.; Morte, E. S. B.; Korn, M. G. A.; Teixeira, L. S. G.; Korn, M.; Costa, A. C. S.; Spectrochim. Acta, Part B 2005, 60, 653 .

8. Nazari, S.; Microchem. J. 2008, 90, 107.
9. Ferreira, S. L. C.; Queiroz, A. S.; Melo, A. S. Q.; Assis, J. C. R.; Korn, M. G. A.; Costa, A. C. S.; J. Braz. Chem. Soc. 1997, 8,621 .

10. Jia, Q.; Kong, X.; Zhou, W.; Bi, L.; Microchem. J. 2008, 89, 82.

11. Stafiej, A.; Pyrzynska, K.; Microchem. J. 2008, 89, 29.

12. Rocha, F. R. P.; Teixeira, L. S. G.; Nóbrega, J. A.; Spectroscopy Lett. 2009, 42, 418.

13. Lee, J.; Lee H. K.; Rasmussen, K. E.; Pedersen-Bjergaard, S.; Anal. Chim. Acta 2008, 624, 253.

14. Naserib, M. T.; Hemmatkhahb, P.; Hosseini, M. R. M.; Assadi, Y.; Anal. Chim. Acta 2008, 610, 135.

15. Rezaee, M.; Assadi, Y.; Hosseini, M. M.; Aghaee, E.; Ahmadi, F.; Berijani, S.; J. Chromatogr., A 2006, 1116, 1.

16. Farajzadeh, M. A.; Bahramb, M.; Mehrb, B. G.; Jonsson, J. A. K.; Talanta 2008, 75, 832.

17. Gharehbaghi, M.; Shemirani, F.; Baghdadi, M.; Anal. Chem. 2009, 89, 21.

18. Anthemidis, A. N.; Ioannou, K. I. G.; Talanta 2009, 79, 86.

19. Aseri, M. T.; Hosseini, M. R. M.; Assadi Y.; Kiani, A.; Talanta 2008, $75,56$.

20. Bidari, A.; Jahromi, Z. E.; Assadi, Y. Hosseini, M. R. M.; Microchem. J. 2007, 87, 6.

21. Pereira, F. P.; Lavilla, I.; Bendicho, C.; Spectrochim. Acta, Part B 2009, 64, 1.

22. Bavili-Tabrizi, A.; J. Hazard. Mater. 2010, 183, 688.

23. Moghadam, M. R.; Shabani, A. M. H.; Dadfarnia, S.; J. Hazard. Mater 2011, 197, 176.

24. Liang, P.; Sang, H. S.; Sun, Z.; J. Colloid Interface Sci. 2006, $304,486$.

25. Chang, X.; Jiang, N.; Zheng, H.; He, Q.; Hu, Z.; Zhai, Y.; Cui, Y.; Talanta 2007, 71, 38.

26. Mashhadizadeh, M.H.;Azimi, M. S.; Pesteh, M.; Sheikhshoaei, I.; Ardekani, M. M.; Karimi, M. A.; Spectrochim. Acta, Part B 2008, 63, 889.

27. Yaman, M.; Kaya, G.; Anal. Chim. Acta 2005, 540, 77.

Submitted: November 29, 2011

Published online: April 19, 2012 